Portland State University

PDXScholar

Summer 2014

\title{
Development, Implementation, and Assessment of a Competency Model for a Graduate Public Affairs Program in Health Administration
}

Jill Jamison Rissi

Portland State University, jrissi@pdx.edu

Sherril B. Gelmon

Portland State University, gelmons@pdx.edu

Follow this and additional works at: https://pdxscholar.library.pdx.edu/pubadmin_fac

Part of the Higher Education Commons, and the Public Administration Commons Let us know how access to this document benefits you.

\section{Citation Details}

Rissi, J. J., \& Gelmon, S. B. (2014). Development, Implementation, and Assessment of a Competency Model for a Graduate Public Affairs Program in Health Administration. Journal Of Public Affairs Education, 20(3), 335-352.

This Article is brought to you for free and open access. It has been accepted for inclusion in Public Administration Faculty Publications and Presentations by an authorized administrator of PDXScholar. Please contact us if we can make this document more accessible: pdxscholar@pdx.edu. 


\title{
Development, Implementation, and Assessment of a Competency Model for a Graduate Public Affairs Program in Health Administration
}

\author{
Jill Jamison Rissi and Sherril B. Gelmon \\ Mark O. Hatfield School of Government, Portland State University
}

\begin{abstract}
Competency-based education has become the norm for professional graduate degree programs. This paper describes the development, implementation, and ongoing validation of a competency model designed for a multifaceted public administration program. The model is based on accreditation standards and competencies promulgated by NASPAA and CAHME, and reflects a unique focus on community-engaged pedagogies. A framework consisting of 10 competencies was implemented in 2011-12 and validated through feedback from stakeholders, alumni, field preceptors, and graduates. A two-dimensional matrix of content coverage and expected levels of competency attainment delineates the articulation of competencies, curriculum, and course content, and provides a framework for program evaluation. Multiple methods for evaluating the competency-based graduate health administration program are described. Ongoing efforts to refine courses, the curriculum, and the competency model are discussed in the context of the program's mission, multiple accreditation standards, assessment of student learning outcomes, and engagement of community stakeholders.
\end{abstract}

KEYWORDS:

health administration, competency assessment

An educational strategy based on competencies and outcomes has quickly become the norm in graduate public administration as well as health administration programs (Clement et al., 2010; Powell, Piskulich, \& Saint-Germain, 2011). Because a robust competency model can help to align practice and academic priorities, graduate programs in public and health administration are working to develop and adopt such models, along with programspecific competencies, curricula, and courses (Getha-Taylor, Hummert, Nalbandian, \&
Silvia, 2013). Conceptually, competency-based programs provide students with the knowledge, skills, and attitudes necessary for successful careers (CAHME, 2013a; Spady, 1978). Recognition of the substantial variation among professional roles and employment settings that graduates enter has shifted the conversation about graduate health administration education from a focus on establishing commonly defined program content to a focus on developing and assessing competencies that are aligned with program mission and students' career goals. 
Our shift to competency-based graduate education was prompted, in part, by concurrent reviews by three specialized accreditors, and involved a comprehensive review of our public and health administration programs. Modest institutional support for the effort included some release time for the lead faculty and limited administrative support to coordinate the review process. All faculty were engaged in the review of individual course content and learning objectives, and some contributed to the self-study by participating in activities related to competency development, curriculum mapping, and the creation and implementation of various evaluation and assessment activities. The results of various information collection activities were integrated into the respective accreditation self-studies.

Despite the growth of competency-based education, challenges persist in identifying appropriate competencies (Spady, 1978) and assessing the development of student competence (Getha-Taylor et al., 2013). Specific concerns include the relationships among competence, program curricula, and course content (Perlin, 2011); course-level teaching, learning, and assessment methods (Calhoun, Wainio et al., 2008; Calhoun, Vincent et al., 2009; Griffith, 2007); and the validity, relevance, and balance among competencies (Clement et al., 2010; Spady, 1978). For health administration specialty tracks, the "gap" between education and practice (Calhoun, Vincent et al., 2009; Griffith, 1998), the increasing complexity of health care organizations (Griffith, 2007), expanding globalization (Counte, Ramirez, \& Aaronson, 2011), and the need to address changing workforce demographics (Putre, 2013) have also been identified as obstacles. However, the greatest challenge to implementing competency-based public administration education may simply be identifying emerging competencies (Getha-Taylor et al., 2013; Op de Beeck \& Hondeghem, 2010). Given the unprecedented pace of health system transformation, the process of developing and assessing tractable administrative competencies presents an especially difficult challenge for health management programs (Clement et al., 2010; Bradley et al., 2008; Hernandez \& Shewchuk, 2008).

This paper describes the development, implementation, and ongoing validation of a competency model designed for a multifaceted public administration program, and focuses specifically on the health administration specialty track. The competency model described is based on accreditation standards and competencies promulgated by NASPAA and the Commission on Accreditation of Healthcare Management Education (CAHME), and was informed by extensive community engagement with practitioners, alumni, and students. Building on the work of others (see, e.g., Aristigueta \& Gomes, 2006; Getha-Taylor et al., 2013; Harlow-Rosentraub \& Perry, 2006; Hewitt, Marshall, \& Badger, 2006), we present (a) a summary of the development process for the competency model; (b) an overview of the two-dimensional assessment matrix that links competencies to courses across the curriculum; and (c) a synopsis of the methods used for assessing student competency attainment and the validity of the competency model.

\section{DEVELOPING THE MODEL: INTEGRATION OF PUBLIC AND HEALTH ADMINISTRATION COMPETENCIES}

Getha-Taylor et al. (2013) identify a number of issues that should be addressed in the development, implementation, and assessment of a competency model. Among the issues noted are the model's capacity to align the academic curriculum with the needs of the practice community; the collection and use of data for program improvement; the balance between stability needed for valid measurement and flexibility to respond to changing needs in the practice environment; and the need to explicitly tie the competency model to the overall curriculum and course content. In addition, the role of the public administrator is characterized by a heightened sensibility toward public service values. In the public realm, "administrators utilize a combination of ethical, professional, democratic, and human values to 
maintain legitimacy" (Deforest Molina \& McKeown, 2012, p. 375). This emphasis on public service values is reflected in the revised 2009 NASPAA accreditation standards (NASPAA, 2009), which also speak specifically to competencies, particularly to their assessment, alignment with program mission, and curricular content as well as associated student learning outcomes (Powell et al., 2011).

Competence in professional education is particularly important due to the implicit obligation of each profession to the society it serves-a contract that gives it rights in exchange for the assurance of quality and effectiveness of professional services (Curry \& Wergin, 1993). Evaluation of students and graduates is intended to ensure competent practice at the time of career entry, and includes assessment of skills and knowledge as well as personal qualities that enable the professional to practice in a socially acceptable manner (McGaghie, 1993). Graduates who enter the workforce prepared to address the challenges of public governance need more than just the general core management competencies that are defined by skill and knowledge acquisition (Kennedy, 2010).

The imperatives of public service values and professional ethics are equally applicable in the context of health administration and system reform (Karoly \& Panis, 2004), where many of the same forces are driving the adoption of competency models in health management education (see, e.g., Clement et al., 2010; Shewchuk, O'Connor, \& Fine, 2006; White, Clement, \& Nayar, 2006). In particular, the 2001 National Summit on the Future of Education and Practice in Health Management and Policy and the subsequent establishment of the National Center for Healthcare Leadership (Calhoun, Vincent et al., 2008) are cited as key drivers of the interest in competency-based education. Groups representing health care executives, such as the Healthcare Leadership Alliance, have also pushed for more attention to competencies (Stefl, 2008). In response to these calls for greater attention to alignment of health management practice and graduate health management education, CAHME transitioned to a competency-based model with revised accreditation standards that were phased in over several years and required as of Fall 2013 (CAHME, 2013b).

\section{Developing the Competency Model: Inte- gration of Multiple Accreditation Standards}

A particular challenge for the development and implementation of a competency model is the need to respond to multiple accrediting bodies. Our degree programs are accredited by three specialized accreditors-NASPAA, CAHME, and the Council on Education for Public Health (CEPH). The Master of Public Administration: Health Administration (MPA: HA) degree is accredited by NASPAA and CAHME, and the Master of Public Administration: Health Management and Policy (MPH:HMP) degree is accredited by CAHME and CEPH. In addition, the MPA and EMPA programs are both accredited by NASPAA, but are beyond the scope of this article. Each accreditor has adopted unique standards and criteria with varying degrees of specificity and expectations for the development of programspecific competencies. Although each one is unique in some respects, "comparisons across the accrediting groups show similar emphases on competencies expected in almost all categories" (Harlow-Rosentraub \& Perry, 2006, p. 201). A comparison of CAHME's four competency domains indicates substantial overlap with NASPAA's five universal required competencies (see Table 1). The mapping to core knowledge areas defined by $\mathrm{CEPH}$ is not as direct, likely due to the broad scope of $\mathrm{MPH}$ programs covered by CEPH. CEPH (2011) identifies required knowledge areas as the foundation for a program's statement of competencies, but expects programs to develop their own competencies.

\section{Developing the Competency Model: Process}

In preparation for accreditation reviews by CAHME (Fall 2012), NASPAA (Spring 2013), and CEPH (Fall 2013), we developed, vetted, and adopted a model consisting of 10 discrete competencies that map directly to curricular 
TABLE 1.

Competency Domains of Relevant Specialized Accreditors

\begin{tabular}{|c|c|c|}
\hline $\begin{array}{l}\text { CAHME } \\
\text { Competency } \\
\text { Domains }\end{array}$ & $\begin{array}{l}\text { NASPAA } \\
\text { Universal Required } \\
\text { Competencies }\end{array}$ & $\begin{array}{l}\text { CEPH } \\
\text { Public Health Core } \\
\text { Knowledge Domains }\end{array}$ \\
\hline $\begin{array}{l}\text { 1. Management } \\
\text { and leadership }\end{array}$ & $\begin{array}{l}\text { 1. To lead and manage in public } \\
\text { governance } \\
\text { 2. To participate in and contribute } \\
\text { to the policy process }\end{array}$ & $\begin{array}{l}\text { 1. Health services administration: planning, } \\
\text { organization, administration, management, } \\
\text { evaluation, and policy analysis of health } \\
\text { and public health programs }\end{array}$ \\
\hline $\begin{array}{l}\text { 2. Critical thinking, } \\
\text { analysis, and } \\
\text { problem solving }\end{array}$ & $\begin{array}{l}\text { 3. To analyze, synthesize, think } \\
\text { critically, solve problems, and } \\
\text { make decisions }\end{array}$ & $\begin{array}{l}\text { 2. Biostatistics: collection, storage, retrieval, } \\
\text { analysis, and interpretation of health data; } \\
\text { design and analysis of health-related } \\
\text { surveys and experiments; and concepts } \\
\text { and practice of statistical data analysis } \\
\text { 3. Epidemiology: distributions and } \\
\text { determinants of disease, disabilities, and } \\
\text { death in human populations; the } \\
\text { characteristics and dynamics of human } \\
\text { populations; and the natural history of } \\
\text { disease and the biologic basis of health } \\
\text { 4. Environmental health sciences: } \\
\text { environmental factors including biological, } \\
\text { physical, and chemical factors that affect } \\
\text { the health of a community }\end{array}$ \\
\hline $\begin{array}{l}\text { 3. Communications } \\
\text { and interpersonal } \\
\text { effectiveness }\end{array}$ & $\begin{array}{l}\text { 4. To communicate and interact } \\
\text { productively with a diverse } \\
\text { and changing workforce } \\
\text { and citizenry }\end{array}$ & $\begin{array}{l}\text { 5. Social and behavioral sciences: concepts } \\
\text { and methods of social and behavioral } \\
\text { sciences relevant to the identification and } \\
\text { solution of public health problems }\end{array}$ \\
\hline $\begin{array}{l}\text { 4. Professionalism } \\
\text { and ethics }\end{array}$ & $\begin{array}{l}\text { 5. To articulate and apply a } \\
\text { public service perspective }\end{array}$ & \\
\hline
\end{tabular}

Sources. CAHME (2013b); NASPAA (2009); CEPH (2011).

structure and course content. Competency model development initiatives reported in the literature suggested that efforts that relied initially on advisory council members and faculty were too cumbersome, and that starting with existing models may be a more efficient approach (Clement et al., 2010).

In developing the model shown in Table 2, we drew on existing competency models ${ }^{1}$ to identify a set of competencies that would be most relevant for the types of careers our graduates seek. In doing so, we identified many elements that are common to the competency models used most widely by CAHMEaccredited programs, as well as elements of competency models used by NASPAA- and $\mathrm{CEPH}$-accredited programs. Our review was consistent with the findings of previous studies that have outlined a number of competency initiatives (Calhoun et al., 2009; Garman \& Johnson, 2006) or presented comparative summaries of the various models (Calhoun, Wainio et al., 2009; Clement et al., 2010). The preliminary competency model was then reviewed for alignment with NASPAA and CAHME accreditation criteria. 
TABLE 2.

Program Competencies for Graduate (Public) and Health Management Students

Students in the MPA-HA and MPH:HMP programs will master the following competencies by graduation, as evident through their demonstrated ability to:

1. Articulate and exemplify the ethics, values, responsibilities, obligations, and social roles of a member of the (public) health services administration profession.

2. Identify and apply relevant theories and frameworks to the practice of (public) health services leadership, management, and policy.

3. Respond to and engage collaboratively with diverse local and global cultures and communities to address challenges in the (public interest) interest of population health.

4. Identify and engage with the key elements of the (public) health policy process.

5. Employ appropriate qualitative and quantitative techniques to investigate, monitor, and manage resource use.

6. Create and manage systems and processes to assess and improve organizational performance.

7. Conceptualize, analyze, and develop creative and collaborative solutions to challenges in (public) health services leadership, management, and policy.

8. Assess challenges and explore solutions to advance cross-sectoral and inter-jurisdictional cooperation in (public) health programs and services.

9. Demonstrate verbal and written communication skills as a (public) health service professional and through interpersonal interactions in groups and in society.

10. Think critically and self-reflectively about emerging issues concerning (public) health services leadership, management, and policy.

In addition to NASPAA Criterion 5, which addresses the requirement to "articulate and apply a public service perspective" (NASPAA, 2009), our accreditation self-study preparation was strongly guided by CAHME Criteria III.A.1-4, regarding the articulation among competencies, curriculum design, course content, and assessment (CAHME, 2013b). Specifically, these criteria require that the program will

- Adopt a set of competencies as the basis of its curriculum and link course content and learning objectives to the competencies;
- Structure its curriculum so that students achieve levels of competency appropriate to graduate education;

- Ensure that course syllabi incorporate current developments in the field and accurately reflect course competencies and content, teaching and assessment methods, and relationship to other courses; and

- Evaluate course instruction and the curriculum and use the results to develop specific plans for maintaining or improving the quality of the teaching and learning environment. 
We addressed the next step in the process, vetting of the model, through a competency self-assessment tool that was piloted with students who graduated in June 2011, and a comparable assessment by field-based preceptors of students in their final field placement at that time. Students' self-assessments indicated that the competencies were robust and relevant to their specific areas of interest. The fieldbased preceptors are leaders or senior-level managers in health services and related organizations, who receive an orientation to the field placement and are responsible for supervision of the students during the placement. Many have worked with our programs with multiple students; alumni frequently serve as preceptors. As a result, most are very familiar with the overall curriculum and often hire the graduates. Their evaluations of the students reinforced the relevance of the competencies as a means of assessing student performance in the workplace.

Substantial input from the Public Administration Division's Advisory Committee and other community stakeholders also validated the model. The competency model was evaluated further during the 2011-12 academic year by the core health program faculty to assure that course-level learning objectives directly and progressively supported competency development across the health program curriculum. This review was also intended to assess the degree of standardization among sections when a given course was taught by more than one faculty member. The core public administration faculty used a similar process to test the competencies and curricular alignment for the other MPA specializations (beyond health). Although these reviews resulted in very few modifications to coursespecific competencies, the structured process was valuable in assisting faculty members to articulate the relationships among course learning objectives, program curricula, and PA Division and CAHME competencies. The review process also served as a means of engaging all faculty (regular, fixed-term, and adjunct) in integrating the competency-based approach into their teaching.

To ensure that the competency model would address the career goals of students in all of our degree programs, meet multiple accreditation standards, and achieve program goals that are unique to our mission, we relied heavily on input from practitioners, alumni, and field-based preceptors in both the public administration and health services communities. These communities had previously validated our agreement upon a common set of vision, mission, and values statements for our division, so it was logical to adopt a single set of competencies that would be relevant to all of our degree programs. In particular, feedback from these groups was instrumental in helping us to assess the degree to which the single set of competencies could (a) be used by faculty, students, and field-based preceptors in assessing all students across all four of our graduate degree programs; (b) provide program-level insights when aggregated by course, specialization, and/ or degree; (c) provide the appropriate balance of standardization and flexibility to be applied in the context of each student's background, experience, and career goals; and (d) demonstrate consistency with the program's mission and the types of jobs graduates seek. Based on feedback from the external groups, we developed parallel competency sets for the general MPA and the MPA:HA that use either the words public or health. We viewed this distinction as being more responsive to accreditation criteria that call for discipline-specific focus, and we carried it through to readings, case studies, and assignments in core courses that can also satisfy the needs of multiple accrediting bodies and the interests of our students.

In contrast to models that place greater emphasis on technical competencies, this model emphasizes analysis, critical thinking, collaboration, communication, and community engagement. These types of interpersonal skills and leadership abilities have been identified as the most important competencies because they 
"transcend the disciplinary and technical work activities of healthcare managers in the workplace" (Clement et al., 2010, p. 168). This focus also reflects the community-engaged pedagogies that are a defining characteristic of our programs, and alumni perceptions of the importance of these competencies for their career success. The competency structure does not, nor is it intended to, eschew the value of analytic and technical skills. We believe that this competency model provides a more explicit recognition of the importance of competencies related to professional attitudes. Thus it is responsive to the criteria of multiple accrediting bodies, and to broader concerns about the focus and balance among competencies that were expressed by practitioners in the public and health administration fields with regard to public service values and professional attitude.

\section{COMPETENCY DEVELOPMENT ACROSS THE CURRICULUM}

Development and validation of the program's competency model is integral to the overall curriculum and course content. Mapping is a recognized approach for "evaluation and restructuring of individual course and curriculum objectives for alignment with program competencies and accreditation requirements" (Perlin, 2011, p. 27). Curriculum mapping is one of our main means for assessing the alignment of our educational process (courses) with our intended educational outcomes (competencies). The mapping process also provided an opportunity for program faculty to reflect on curricular design in three ways: (a) assessing any changes or evolution of courses in terms of their competency focus; (b) assessing the degree to which course ratings are reflected in specific course competencies or learning objectives identified in course syllabi, and vice versa; and (c) evaluating how well the overall curriculum reflects the program's stated competencies in terms of breadth and depth.

This process of competency development starts with building knowledge and recall of course material and moves to comprehension with the ability to express the meaning of what was learned. Application and analysis follow, and synthesis of the material occurs in latter parts of courses and the curricula. Evaluation reflects judgmental ability in the knowledge and use of the material. Students are expected to develop course-specific skills within each competency domain. Three categories of expected level of skill attainment are adapted from Bloom's taxonomy (1956), and are defined as follows: Basic knowledge and comprehension of subject matter; Intermediate ability to apply knowledge to analyze a problem; and Advanced ability to evaluate, judge, and synthesize information. The progression to higher-order verbs within Bloom's taxonomy is intended to reflect expectations associated with graduate-level health administration education.

In addition to the level of competency attainment, we added a second metric reflecting the extent, or intensity, of coverage of a given competency within each course. A twodimensional matrix was developed that reflects both the intensity of coverage within a given course as well as the expected level of student competency attainment. Intensity/extent of coverage scoring was defined as follows: Limited exposure to or development of topical knowledge and skills; Moderate coverage of the knowledge domain and/or experiential learning; and Extensive development of topical knowledge and applied skill development (see Table 3). When presented in color, each dimension can be presented in a light, medium, or dark shade in order to highlight the progression from basic to advanced competency attainment, and limited to extensive intensity of content coverage across the curriculum.

Competency in each of the 10 domains is developed across the curriculum through the sequencing of courses and is guided by faculty advising and through the structuring of prerequisites. This strategy creates a flexible framework, addressing both breadth and depth of competency attainment. Students generally begin their program of study with "core" 
disciplinary courses in Public Administration (for MPA:HA) and Public Health (for MPH:HMP), along with "concentration core" courses such as Health Systems Organization and Organizational Behavior in Health Services that are taken early in the program of study. Together, the core and concentration core courses form the foundation for courses that are taken midway through the program of study and that deliver specific health management knowledge in areas such as finance, law, quality, ethics, economics, and policy. Courses taken late in the program of study — such as strategic management, program evaluation, continuous improvement, and the culminating field experience-integrate and extend competency development across the curriculum, and they include substantial applied and experiential components.

\section{ASSESSMENT OF THE MODEL AND STUDENT COMPETENCY ATTAINMENT}

We used multiple approaches to assess the competency model and to evaluate students' competency attainment at the course and curricular levels. The criteria by which the goals and value of higher education are determined remains a contested issue, particularly in the context of competency-based accreditation (see, e.g., Law, 2010; Stensaker, 2011). Arguably, a significant driver of the transition to competency-based education has been the need ensure that student capabilities are developed in response to the needs of external stakeholders—namely, employers (Ewell, 2008). Thus, the criteria for assessing the relevance of the competency model for students' careers are somewhat unique to a given program. Our assessment of the competency model included the engagement of external stakeholders and alumni as well as multilevel strategies for the assessment of current students.

\section{Assessment of the Competency Model}

In May 2012, Public Administration (PA) Division Advisory Council members participated in a modified focus group process regarding the new competency model and its efficacy in preparing graduates for careers that reflect the community-engaged, public serviceoriented nature of the program. Because the council includes members from the public, nonprofit, and health sectors, we were able to obtain a broad range of perspectives on the model. Feedback from council members, most of whom employ program graduates, indicated that the students were well prepared for a range of careers. In particular, council members noted the community-oriented perspective of program graduates, as well as the program's flexibility and synergy, as uniquely distinguishing features. They characterized the curriculum as "an agency of change for public leadership." Noting the general lack of knowledge about the transition to a competency-based model of graduate education, a key suggestion from the council was the need for a "tag line" that could succinctly communicate the distinctive nature of the program.

In addition to advisory council feedback, we sought input from program alumni who completed the program between 2007 and 2011. The online alumni survey yielded a response rate of $38 \%$ ( $n=154 ; 37 \%$ of MPA:HA graduates and $39 \%$ of MPH:HMP graduates). The primary objective of the survey was to assess the overall effectiveness and outcomes of the division's MPA:HA and MPH:HMP programs. Specifically, survey findings were used to validate the competency model, assess the curriculum, and identify strengths and areas for improvement. Survey results also provided insights regarding student needs in the context of accreditation criteria.

Alumni job placement. Respondents reported a wide range of employing organizations, although response categories may have forced respondents to choose from among potentially overlapping roles. Just over one third (37\%) of respondents reported being employed in a professional, technical, or research staff/analyst position, consistent with responses regarding job settings in educational institutions and government agencies (37\% combined). Col- 
TABLE 3.

Matrix of Course Content (L, M, E) and Expected Level of Competency Attainment (B, I, A) Across the Curriculum

\section{Course Name}
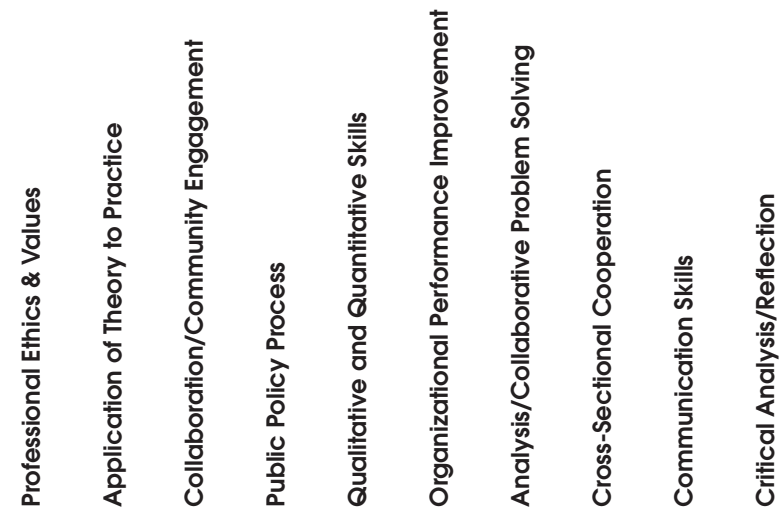

\begin{tabular}{|c|c|c|c|c|c|c|c|c|c|c|}
\hline Public Administration & $E / B$ & $\mathrm{M} / \mathrm{I}$ & $E / I$ & $M / I$ & $-1-$ & $-/-$ & $\mathrm{M} / \mathrm{I}$ & $-1-$ & $\mathrm{M} / \mathrm{I}$ & $-1-$ \\
\hline Administrative Ethics and Values & $E / I$ & $\mathrm{M} / \mathrm{A}$ & $\mathrm{L} / \mathrm{l}$ & $-1-$ & $-1-$ & $-1-$ & L/A & $-/-$ & $M / I$ & $\mathrm{M} / \mathrm{A}$ \\
\hline Public Policy Origins and Processes & $-1-$ & $\mathrm{M} / \mathrm{A}$ & $-1-$ & E/A & $-1-$ & $-1-$ & L/I & $\mathrm{M} / \mathrm{A}$ & $\mathrm{M} / \mathrm{I}$ & $\mathrm{M} / \mathrm{I}$ \\
\hline Administrative Law and Policy & $M / l$ & $E / A$ & $-1-$ & $E / I$ & $-1-$ & $-1-$ & $E / A$ & L/I & $M / A$ & $M / A$ \\
\hline Administrative Theory and Behavior & $-/-$ & $E / I$ & L/B & $-1-$ & L/B & $\mathrm{M} / \mathrm{A}$ & $E / l$ & $-1-$ & $M / I$ & $E / I$ \\
\hline Analytic Methods in Public Administration I & $-1-$ & $\mathrm{M} / \mathrm{A}$ & L/B & $\mathrm{L} / \mathrm{I}$ & $E / I$ & $\mathrm{M} / \mathrm{I}$ & $M / /$ & $-1-$ & $\mathrm{L} / \mathrm{I}$ & $\mathrm{L} / \mathrm{I}$ \\
\hline Analytic Methods in Public Administration II & $-1-$ & $\mathrm{M} / \mathrm{A}$ & L/B & L/I & $E / I$ & $M / l$ & $\mathrm{E} / \mathrm{A}$ & $-1-$ & $\mathrm{L} / \mathrm{I}$ & $\mathrm{L} / \mathrm{I}$ \\
\hline Public Budgeting & $M / I$ & $M / I$ & $-1-$ & L/I & $M / I$ & $L / /$ & $\mathrm{M} / \mathrm{A}$ & $\mathrm{L} / \mathrm{l}$ & $-1-$ & L/I \\
\hline Human Resource Management & L/B & $\mathrm{M} / \mathrm{I}$ & $-1-$ & $-1-$ & $-1-$ & $\mathrm{L} / \mathrm{l}$ & $\mathrm{M} / \mathrm{A}$ & $-1-$ & $\mathrm{M} / \mathrm{A}$ & $\mathrm{L} / \mathrm{B}$ \\
\hline Organizational Behavior in Health Orgs & $M / B$ & $E / B$ & $-1-$ & $-1-$ & $\mathrm{L} / \mathrm{B}$ & $M / I$ & $\mathrm{E} / \mathrm{l}$ & $-1-$ & $M / l$ & $E / I$ \\
\hline Marketing in Health Care & $-1-$ & $\mathrm{M} / \mathrm{I}$ & $E / l$ & $-1-$ & $\mathrm{M} / \mathrm{I}$ & $\mathrm{M} / \mathrm{I}$ & E/A & $-1-$ & E/A & $-1-$ \\
\hline Leadership and Governance in Health & $\mathrm{M} / \mathrm{A}$ & L/I & $\mathrm{M} / \mathrm{B}$ & $-1-$ & $-1-$ & L/l & $\mathrm{M} / \mathrm{A}$ & $-1-$ & $\mathrm{M} / \mathrm{A}$ & $E / A$ \\
\hline Health Administration & $\mathrm{M} / \mathrm{B}$ & $-1-$ & $-1-$ & $\mathrm{L} / \mathrm{l}$ & L/B & $\mathrm{L} / \mathrm{I}$ & $-1-$ & $-1-$ & $\mathrm{M} / \mathrm{I}$ & $-1-$ \\
\hline Health Policy & L/I & $\mathrm{M} / \mathrm{I}$ & $-1-$ & E/A & $-1-$ & $-/-$ & $\mathrm{M} / \mathrm{A}$ & $\mathrm{L} / \mathrm{I}$ & $M / I$ & $\mathrm{M} / \mathrm{A}$ \\
\hline Values and Ethics in Health & $\mathrm{E} / \mathrm{A}$ & E/A & L/B & $-1-$ & $-1-$ & $-1-$ & $M / I$ & $-1-$ & $\mathrm{M} / \mathrm{I}$ & E/A \\
\hline Health Systems Organization & $M / I$ & L/B & $M / I$ & $\mathrm{M} / \mathrm{B}$ & $-1-$ & L/B & $\mathrm{M} / \mathrm{I}$ & $\mathrm{M} / \mathrm{l}$ & $\mathrm{M} / \mathrm{I}$ & $\mathrm{L} / \mathrm{B}$ \\
\hline Advanced Health Policy & $\mathrm{L} / \mathrm{I}$ & $\mathrm{M} / \mathrm{A}$ & $-1-$ & E/A & $-1-$ & $-1-$ & $E / A$ & $\mathrm{M} / \mathrm{A}$ & $M / I$ & E/A \\
\hline Strategic Management in Health Services & L/A & $\mathrm{M} / \mathrm{A}$ & $-1-$ & $M / I$ & $\mathrm{M} / \mathrm{A}$ & $\mathrm{E} / \mathrm{A}$ & $\mathrm{E} / \mathrm{A}$ & $-1-$ & M/A & $E / A$ \\
\hline Health Care Law and Regulation & $E / l$ & I/M & $-1-$ & $E / l$ & $-1-$ & $-1-$ & $\mathrm{M} / \mathrm{A}$ & $\mathrm{L} / \mathrm{I}$ & M/A & $\mathrm{M} / \mathrm{A}$ \\
\hline Continual Improvement in Heath & $-1-$ & $M / I$ & $L / B$ & $-1-$ & $E / I$ & $E / A$ & $E / A$ & $-1-$ & $\mathrm{M} / \mathrm{B}$ & $M / I$ \\
\hline Health Care Information Systems Mgmt & L/B & $-1-$ & $-1-$ & $M / I$ & $-1-$ & $\mathrm{M} / \mathrm{A}$ & $\mathrm{M} / \mathrm{I}$ & $-1-$ & L/B & L/I \\
\hline Health Services HR Management & $\mathrm{M} / \mathrm{I}$ & $\mathrm{M} / \mathrm{I}$ & $-1-$ & $-1-$ & $-1-$ & $\mathrm{L} / \mathrm{I}$ & M/A & $-1-$ & M/A & L/B \\
\hline Introduction to Health Economics & $-1-$ & $M / I$ & $-1-$ & E/A & $M / l$ & $\mathrm{M} / \mathrm{A}$ & $\mathrm{M} / \mathrm{A}$ & $-1-$ & $-1-$ & $\mathrm{M} / \mathrm{I}$ \\
\hline Financial Management in Health Services & $\mathrm{L} / \mathrm{I}$ & $-1-$ & $-1-$ & $-1-$ & $\mathrm{E} / \mathrm{A}$ & $\mathrm{E} / \mathrm{A}$ & $\mathrm{E} / \mathrm{A}$ & $-1-$ & L/B & $\mathrm{M} / \mathrm{A}$ \\
\hline Program Evaluation and Mgmt in Health & $\mathrm{L} / \mathrm{l}$ & $E / I$ & $\mathrm{M} / \mathrm{l}$ & $-1-$ & $\mathrm{M} / \mathrm{l}$ & $E / A$ & $E / A$ & $-1-$ & $E / A$ & L/l \\
\hline Principles of Health Behavior (PSU/SCH) & L/B & $\mathrm{M} / \mathrm{I}$ & $\mathrm{M} / \mathrm{I}$ & $-1-$ & $-1-$ & $-1-$ & $\mathrm{M} / \mathrm{I}$ & $-1-$ & $\mathrm{M} / \mathrm{I}$ & $\mathrm{L} / \mathrm{I}$ \\
\hline Epidemiology Survey (PSU/SCH) & L/B & $M / I$ & $-1-$ & $-1-$ & $\mathrm{E} / \mathrm{A}$ & $-1-$ & I/M & $-1-$ & $\mathrm{M} / \mathrm{I}$ & $\mathrm{M} / \mathrm{I}$ \\
\hline Concepts in Environmental Health (PSU/SCH) & $\mathrm{M} / \mathrm{I}$ & $M / I$ & $M / l$ & L/I & $\mathrm{M} / \mathrm{I}$ & $-1-$ & $-1-$ & $\mathrm{L} / \mathrm{l}$ & L/B & $-1-$ \\
\hline Introduction to Biostatistics (OHSU) & $-1-$ & $M / l$ & $-1-$ & $-1-$ & $E / A$ & $-1-$ & L/I & $-1-$ & $M / I$ & $-1-$ \\
\hline
\end{tabular}


lectively, health care delivery settings (general health services, acute care, public health, behavioral health, and community clinics) accounted for $34 \%$ of job placements, consistent with the $31 \%$ of graduates in managerial positions. Of note, $17 \%$ of all graduates were employed with a government agency other than a public health department. In addition, although the overall numbers are small, a larger proportion of MPH:HMP graduates $(18 \%)$ than MPA:HA graduates $(10 \%)$ are employed in government positions, while a larger percentage of MPA:HA graduates $(45 \%)$ are employed in health services delivery settings relative to their MPH:HMP counterparts $(23 \%)$.
Alumni self-assessment of competency. Results of the alumni survey suggested that while targets for graduate employment were met, the contribution of the newly established competencies to that success was mixed. The vast majority of respondents (91\%) were employed within six months of graduation; the remaining $9 \%$ were either pursuing further education or did not seek employment for other reasons. Among employed respondents, 69\% indicated that their degree was "extremely" or "very" important in obtaining their current job, promotion, or transfer. Responses to this question varied by type of degree: The MPH:HMP graduates reported greater importance of their master's degree (42\% extremely important;

TABLE 4.

Perceptions of Recently Graduated Alumni Regarding Competency Attainment

\begin{tabular}{|c|c|c|c|c|c|}
\hline Question & $\begin{array}{l}\text { Well } \\
\text { Prepared }\end{array}$ & $\begin{array}{l}\text { Quite a Bit } \\
\text { Prepared }\end{array}$ & $\begin{array}{l}\text { Somewhat } \\
\text { Prepared }\end{array}$ & $\begin{array}{l}\text { A Little Bit } \\
\text { Prepared }\end{array}$ & $\begin{array}{l}\text { Not at All } \\
\text { prepared }\end{array}$ \\
\hline $\begin{array}{l}\text { 1. Articulate and exemplify ethics, } \\
\text { values, and social roles of a public } \\
\text { service professional. }\end{array}$ & $49 \%$ & $31 \%$ & $15 \%$ & $5 \%$ & $0 \%$ \\
\hline $\begin{array}{l}\text { 2. Identify and apply relevant theories } \\
\text { and frameworks. }\end{array}$ & $27 \%$ & $46 \%$ & $24 \%$ & $3 \%$ & $0 \%$ \\
\hline $\begin{array}{l}\text { 3. Respond to and engage with } \\
\text { diverse cultures and communities. }\end{array}$ & $22 \%$ & $39 \%$ & $32 \%$ & $7 \%$ & $0 \%$ \\
\hline $\begin{array}{l}\text { 4. Identify key elements and engage } \\
\text { with the policy process. }\end{array}$ & $27 \%$ & $31 \%$ & $34 \%$ & $7 \%$ & $2 \%$ \\
\hline $\begin{array}{l}\text { 5. Employ appropriate qualitative } \\
\text { and quantitative techniques. }\end{array}$ & $27 \%$ & $34 \%$ & $29 \%$ & $8 \%$ & $2 \%$ \\
\hline $\begin{array}{l}\text { 6. Create and manage systems to im- } \\
\text { prove organizational performance. }\end{array}$ & $32 \%$ & $42 \%$ & $17 \%$ & $8 \%$ & $0 \%$ \\
\hline $\begin{array}{l}\text { 7. Conceptualize, analyze, and } \\
\text { develop solutions to challenges } \\
\text { in leadership, management } \\
\text { and policy. }\end{array}$ & $31 \%$ & $32 \%$ & $32 \%$ & $3 \%$ & $2 \%$ \\
\hline $\begin{array}{l}\text { 8. Assess challenges and explore } \\
\text { solutions to advance coopera- } \\
\text { tion in programs and services. }\end{array}$ & $17 \%$ & $27 \%$ & $41 \%$ & $12 \%$ & $3 \%$ \\
\hline $\begin{array}{l}\text { 9. Demonstrate verbal, written and } \\
\text { interpersonal communication skills. }\end{array}$ & $58 \%$ & $29 \%$ & $12 \%$ & $2 \%$ & $0 \%$ \\
\hline 10. Think critically and self-reflectively. & $51 \%$ & $36 \%$ & $12 \%$ & $2 \%$ & $0 \%$ \\
\hline
\end{tabular}


$31 \%$ very important) relative to MPA:HA graduates (33\% extremely important; $22 \%$ very important).

Although the current competency model was not in place when most of the alumni respondents were enrolled in the program, the 2012 alumni survey included questions regarding the degree to which graduates felt the program prepared them to demonstrate these competencies (see Table 4). The competencies that respondents reported as being most strongly supported by their graduate program include communication skills and critical thinking. Overall, $87 \%$ percent of alumni stated that they felt "well" or "quite" prepared with regard to both communication and critical thinking competencies. Other strong (e.g., "well" or "quite" prepared) responses included competencies regarding ethics and values (80\%); system management and organizational performance (74\%); and the application of theory to practice $(73 \%)$. Not surprisingly, competency attainment scores were higher among 2010 and 2011 graduates than among alumni who graduated in earlier years.

Just under two thirds of respondents indicated that they felt "well" or "quite" prepared by the program to work collaboratively with diverse communities (61\%); to use appropriate research and statistical methods (61\%); to conceptualize, analyze, and develop solutions to leadership, management and policy issues (63\%); and to engage in the public policy process $(58 \%)$. For all competencies except "Assess challenges and explore solutions to advance cross-sectoral and inter-jurisdictional cooperation in public programs and services," respondents rated their preparation as adequate or better. Again, responses among more recent graduates indicated higher levels of competency attainment on these measures, possibly because those surveyed had graduated before the new model was implemented and thus were less aware of the model and less cognizant of competency-based education in general.

\section{Field Preceptor Assessment of the Model and Student Competency}

Field preceptors also provided an important dimension in the overall assessment of student competency. Because field placement preceptors are professionals who are currently working in health system settings and are familiar with our health administration program, their assessments of student competency and the relevance of the student's program of study provided particularly useful information for evaluating the competency model and the curriculum. Before implementation of the competency model, preceptors routinely completed assessments of students' performance. In Spring 2011, following initial adoption of the competency model, the preceptor survey was revised to include the 10 PA Division competencies and pilot tested. Based on the pilot survey, several minor changes were implemented in AY 2011-12 to reflect the revised competencies. Field preceptors were asked to evaluate each of the $10 \mathrm{com}$ petencies in the model and to rate the level of attainment of each competency for individual students. The consistency among program goals, the competency model, and students' career objectives was supported by field preceptor responses regarding the knowledge and skills that are most needed and sought in current health administration recruitment efforts. In aggregate, preceptors' ratings of students' competency attainment in AY 2011-12 was 2.9 on a 3-point scale.

\section{Student Self-Assessment of Competency Attainment}

Competency attainment among current students is evaluated through an exit survey administered to students as they complete the required organizational experience, and through course-level assessments or competencies associated with specific course content. Health program students' assessment of competency attainment across all 10 competencies at, or near, the time of graduation was 2.8 on a 3 -point scale (Table 5). Among MPA:HA students, the average selfassessment of competency with regard to communication skills was 3.0 while lower scores 
TABLE 5.

Student Assessment of Competency Attainment; AY 2011-12

PA Division Competency MPH:HMP

MPA:HA

\begin{tabular}{|c|c|c|c|}
\hline Q1 & Articulate and exemplify professional ethics and values & 2.8 & 2.9 \\
\hline Q2 & Apply theory to practice & 2.8 & 2.7 \\
\hline Q3 & Engage with diverse communities & 2.5 & 2.7 \\
\hline Q4 & Engage with the policy process & 2.8 & 2.7 \\
\hline Q5 & Apply qualitative and quantitative research techniques & 2.8 & 2.6 \\
\hline Q6 & Manage systems and processes to improve performance & 2.9 & 2.8 \\
\hline Q7 & Develop solutions to policy, leadership and management challenges & 2.9 & 2.9 \\
\hline Q8 & Advance cross-sector cooperation & 2.5 & 2.5 \\
\hline Q9 & Demonstrate written, verbal and interpersonal communication skills & 3.0 & 3.0 \\
\hline Q10 & Demonstrate critical and self-reflective thinking & 2.9 & 3.0 \\
\hline
\end{tabular}

were reported for "challenges/solutions that advance cooperation" (2.5) and for the ability to "engage with diverse cultures \& communities" (2.5). Similar scores were reported by MPH: HMP students, for whom "communication" and "critical thinking" ratings reflected high levels of self-assessed competency (3.0 for each). Lower scores were reported for the "appropriate selection and application of qualitative and quantitative methods" (2.6), and for competency in addressing "challenges/solutions that advance cooperation" (2.5).

It is important to note several limitations of student self-assessment data. Self-assessments may be subject to response bias, which may have been exacerbated by the heightened attention to competency assessment during the coincidental competency model implementation and self-study time periods. Second, the consistency of student ratings suggests that the 3-point scale may lack sensitivity. Although preceptor and faculty ratings of student competency attainment suggest that the program curriculum is effective, a more sensitive scale might provide a more detailed and nuanced evaluation and highlight areas for further improvement. For these reasons, a 5-point scale will be utilized for future assessments of competency attainment across the curriculum to ensure that all students attain the expected level of competence for all measures.

At the course level, students rate their level of competency attainment for each competency area that is associated with that course on a 5-point scale. Program competencies may be assessed directly or, in recognition of instructional autonomy, through course learning objectives that are stated in the syllabus and linked to program-level competencies. The competency to curriculum matrix we presented previously (see Table 3) identifies the programlevel competencies developed through each required course as well as expected levels of program competency attainment across the curriculum. Because a given student may or may not participate in any given elective course, 
those courses are not included in the overall competency development matrix. Data are summarized and available for review by individual course instructors and across sections of the same course. For example, the Health Systems Organization course is taught by multiple faculty members and associated with four course-specific competencies that are associated with one or more program-level competencies. A summary of evaluations for this course that were conducted during AY 2011-12 indicated that students across all sections were achieving reasonably high levels of self-rated competency attainment, but also revealed some differences among sections (Table 6).

\section{USE OF EVALUATION RESULTS FOR PROGRAM IMPROVEMENT}

Based on the assessment results, several changes were made to the curriculum. For the MPA:HA degree, the course in Health Systems Organization was made a requirement, ensuring that students have both a conceptual and a practical understanding of health systems. Because the content knowledge and skills taught in this course are foundational to many other courses, it was also made a prerequisite to several other courses in both degree programs. A second change was the designation of several other course prerequisites to ensure greater continuity in the developmental learning process and progression from basic to intermediate or advanced competency attainment. Finally, elements of the curriculum were reorganized to ensure adequate health-specific knowledge, skills, and professional perspectives. This change merged skill development electives and specialization electives into a single category of elective courses. Although this change increased the number of required courses, it did not change the total credits for the degree.

In addition to changes to the current curriculum, priority areas for further curriculum development were also identified. In particular, feedback from the advisory council and program alumni noted the increasing importance of alternative payment methodologies and health information technologies precipitated by ongoing system reform. Efforts to enhance curricular coverage of these newly identified areas and to map related course learning objectives to the competency model are ongoing.

TABLE 6.

Averages for Student Self-Assessment of Course-Level Competency Attainment

\section{PAH 574: Health Systems Organization}

Self-Assessed Course-Level Competency Attainment

Course-Level Competency (Program Competency/ies)

\begin{tabular}{|c|c|c|l|}
\hline Section A & Section B & Section C & \\
\hline 4.4 & 4.4 & 4.1 & Apply systems thinking to health system issues (6 \& 7) \\
\hline 4.2 & 4.5 & 4.1 & Identify elements of the health system (2) \\
\hline 4.3 & 4.7 & 4.1 & Articulate \& analyze health system issues $(5,9 \& 10)$ \\
\hline 3.8 & 4.2 & 3.9 & Apply ethical principles to health system issues (1) \\
\hline
\end{tabular}


A final dimension of program improvement focused on competency assessment. These changes included revisions to existing tools and the development of additional mechanisms to create a student-specific portfolio of measurements over the length of the curriculum. Specifically, greater emphasis was placed on assessments of competency attainment both early in the program and at the point of the culminating experience, and the assessment mechanisms were standardized for all students.

Throughout the competency development, implementation, and evaluation process, council members, stakeholders, and alumni remarked on the value of the program's "flexibility" and "synergy" as uniquely distinguishing features, characterizing the program as "an agent of change for public leadership" across the fields of specialization. As the council members in particular noted, these features reflect our mission, the community-engaged and publiclyoriented program attributes our students seek, and the characteristics we seek among applicants to the program.

\section{RECOMMENDATIONS AND CONCLUSIONS}

Health administration is likely to continue to be one of the fastest-growing specializations within public affairs (Andersen, Howard, \& Schneller, 2004; Marshall \& Hewitt, 2006). At the same time, the magnitude and pace of health system reforms call for increased integration, collaboration, and accountability. In combination, these forces are driving the need to review and revise competency models, competencies, curricula, and course content to ensure that students are provided with current and relevant knowledge, skills, and professional attributes.

Partially in recognition of these forces, accreditation criteria for both NASPAA and CAHME have been modified in recent years. These modifications accommodate the need for flexible standards and broad guidelines that will streamline the accreditation process. However, a considerable investment of time and effort will be required for health administration programs to complement the historical focus on technical and analytic skills, to a competency model that places greater emphasis on professional and interpersonal skills. Our experience suggests that aligning the program mission, competency model, competencies, curriculum and course content is the first step in that process. Programs must also develop mechanisms to evaluate the extent to which competencies are taught and evaluated within individual courses, to assess competency attainment across the curriculum, and to engage with multiple stakeholders to assure the ongoing relevance of the competency model and the curriculum.

A key element of the relationships among competencies, curriculum, and course content is the two-dimensional assessment approach. The first dimension addresses course-level teaching and learning of a particular knowledge/ skill, specifically the amount of course content in that area. The second dimension addresses the expected level of competency attainment, specifically the student's ability to apply knowledge and skills to resolve an actual or simulated situational context.

Our program, like many other health administration specialty tracks, attracts nearly equal numbers of in-service and pre-service students. Characteristics that distinguish the in-service student from the pre-service student include (a) focus on the big picture rather than isolated tasks that allows in-service students to apply their knowledge and skill to novel situations; (b) flexibility in response to new situations that allows students to think more broadly about both the technical and the social dimensions of a problem; and (c) the ability to assess trends and identify patterns, and thus develop an integrated, multidimensional response to administrative and policy issues (Van Gelder \& Dougherty, 2012). Diversity with respect to age, race/ethnicity, career goals, and work experience among students adds to the complexity. The development, imple- 
mentation, and assessment of a competency model that is sensitive to the range of students' interests and abilities represents a substantial challenge to competency-based education.

Based on our experience with multiple specialty tracks, health system reform, and a diverse student body, we have identified a number of issues that should be considered by programs seeking accreditation under the new NASPAA and CAHME standards.

1. Competencies should be aligned with the program's mission and the needs of community stakeholders within the practice community. Reliance on existing models is an excellent starting point, but these will be more relevant if tailored to the program's unique context through the engagement of alumni, current students, field placement preceptors, and relevant stakeholders in the development, vetting, and evaluation of the program's competency model, competencies, and curriculum. This will help ensure that graduates leave the program well prepared for the jobs they seek.

2. Programs should review relevant competency models and accreditation criteria to identify common elements among the various domains and standards. In addition, they should actively consider how evolution within the field-particularly the current emphases on accountability, integration, and community engagement-might influence the competencies that are needed by current and future public affairs and health system administrators; how existing competency models might be modified to reflect the types of knowledge and skills that will be needed within a transformed system; and how research topics, methods, and findings should be incorporated into the classroom.

3. Collection, analysis, and utilization of data for program improvement should address the validity and relevance of the competency model and program competencies as well as their progressive development across the curriculum and through individual courses. Data sources should provide sufficient triangulation (e.g., self-assessment by students; evaluations conducted by faculty and field preceptors; and surveys or other feedback from alumni and community stakeholders) to assure confidence in the logic of the competency model, and metrics should highlight areas in which students are succeeding as well as areas in which competency expectations are not being met.

4. Programs should seek to balance the stability needed to measure progress with the flexibility needed to respond to a dynamic environment. The logical relationships among mission, model, competencies, curriculum, and courses should reflect flexibility and instructional autonomy at the most granular level of course content as well as long-term stability at the level of the mission and competency model. Modifications to competencies and curriculum will fall somewhere in the middle and are likely to be dependent on the stage of implementation of competency-based education within the overall program. In the particular context of health administration, ongoing system transformation will likely require programs to regularly reevaluate the relevance and validity of the competencies.

Although we focus on the experience of our health administration programs, we believe that the experience, competency model, curriculum mapping, and assessment modalities presented may help other public management programs to balance achievement of their missions with the requirements of multiple accrediting bodies. Although the terminologies are not identical, the core competencies with regard to leadership, collaboration, communication, and professionalism are remarkably similar. Given the substantial overlap among the domains and core management competencies identified by NASPAA and CAHME, 
and arguably the American Association of Collegiate Schools of Business (AACSB) and $\mathrm{CEPH}$, programs have an opportunity to streamline their competency approaches to meet the expectations of multiple accreditors. In the meantime, public administration programs with specialty tracks in health management and policy will need to continue to monitor changes in the public service and health service sectors and respond with changes in the curriculum to reflect evolving competency expectations.

\section{NOTES}

1 In addition to competency models developed for public administration and business administration, many health administration programs use or draw upon competency models developed by the $\mathrm{Na}$ tional Center for Healthcare Leadership (NCHL), American College of Healthcare Executives (ACHE), Veterans Administration (VA), Saint Louis University School of Public Health (SLU), and the Association to Advance Collegiate Schools of Business (AACSB).

\section{REFERENCES}

Andersen, R. C., Howard, C., \& Schneller, E. (2004). Contemporary models for accreditation: Lessons for health administration education and accreditation. Journal of Health Administration Education, 21(2), 185-226.

Aristigueta, M., \& Gomes, K. M. B. (2006). Assessing performance in NASPAA graduate programs. Journal of Public Affairs Education, 12(1), 1-18.

Bloom, B. S. (1956). Taxonomy of educational objectives: Handbook 1: Cognitive domain. New York: Longman.
Bradley, E. H., Cherlin, E., Busch, S. H., Epstein, A., Helfland, B., \& White, W. D. (2008). Adopting a competency-based model: Mapping curricula and assessing student progress. Journal of Health Administration Education, 25(1), 27-51.

Calhoun, J. G., Vincent, E. T., Calhoun, G. L., \& Brandsen, L. E. (2008). Why competencies in graduate health management and policy education? Journal of Health Administration Education, 25(1), $17-35$.

Calhoun, J. G., Wainio, J. A., Sinioris, M. E., Decker, M., Hearld, L. R., \& Brandsen, L. E. (2009). Outcomes-based health management education: Baseline findings from a national curriculum development demonstration project. Journal of Health Administration Education, 26(3), 171-191.

Clement, D. G., Hall, R. S., O'Connor, S. J., Qu, H., Stefl, M. E., \& White, A. W. (2010). Competency development and validation: A collaborative approach among four graduate programs. Journal of Health Administration Education, 27(3), 151-173.

Commission on Accreditation of Healthcare Management Education (CAHME). (2013a). CAHME Accreditation Fosters High Quality Professional Education. Retrieved from http://www.cahme.org/ AccreditationEducation.html

(2013b). Fall 2013 Criteria for Accreditation. Retrieved from http://cahme.org/Resources/ Fall2013_CriteriaForAccreditation.pdf

Council on Accreditation of Public Health Education (CEPH). (2011). Accreditation Criteria: Public Health Programs. Retrieved from http://ceph.org/ assets/PHP-Criteria-2011.pdf

Counte, M. A, Ramirez, B., \& Aaronson, W. (2011). Global healthcare management education: Essential competencies and major curricular challenges. Journal of Health Administration Education, 28(3), 227-236.

Curry, L., \& Wergin, J. F. (1993). Setting priorities for change in professional education. In L. Curry, J. F. Wergin, \& Associates. Educating professionals: Responding to new expectations for competence and accountability (pp. 316-327). San Francisco: Jossey-Bass. 
Deforest Molina, A., \& McKeown, C. L. (2012). The heart of the profession: Understanding public service values. Journal of Public Affairs Education, 18(2), 375-396.

Ewell, J. (2008). U.S. accreditation and the future of quality assurance. Washington, DC: The Council for Higher Education.

Garman, A. N., \& Johnson, M. P. (2006). Leadership competencies: An introduction. Journal of Healthcare Management, 51(1), 13-17.

Getha-Taylor, H., Hummert, R., Nalbandian, J., \& Silvia, C. (2013). Competency model design and assessment: Findings and future directions. Journal of Public Affairs Education, 19(1), 141-171.

Griffith, J. R. (1998). Can you teach the management technology of health administration? A view of the 21st century. Journal of Health Administration Education, 16(3), 321-338.

(2007). Improving preparation for senior management in healthcare. Journal of Health Administration Education, 24(1), 11-32.

Harlow-Rosentraub, K., \& Perry, J. (2006). Public affairs and healthcare administration: Crosscutting competencies and multiple accreditation challenges for academic programs. Journal of Public Affairs Education, 12(2), 197-211.

Hernandez, S. R., \& Shewchuk, R. (2008). Competencies and curriculum content: What works for our programs? Journal of Health Administration Education, 25(2), 81-85.

Hewitt, A. M., Marshall, B. S., \& Badger, K. H. (2006). A proposed methodology for the infrastructure development of NASPAA programs with specialty tracks: The case of health policy and management. Journal of Public Affairs Education, 12(2), 125-141.

Karoly, L. A., \& Panis, C. W. A. (2004). The 21st century at work: Forces shaping the future workforce and workplace in the United States. Santa Monica, CA: Rand Corporation.

Kennedy, S. S. (2010). The pedagogy of "governance." Journal of Public Affairs Education, 16(4), 607-619.

Law, D. C. S. (2010). Quality assurance in postsecondary education. Quality Assurance in Education, 18(1), 64-77.
Marshall, B. S., \& Hewitt, A. M. (2006). A national profile of NASPAA programs with health specialty tracks. Journal of Public Affairs Education, 12(2), 143-163.

McGaghie, W. C. (1993). Evaluating competence for professional practice. In L. Curry, J. F. Wergin, \& Associates. Educating Professionals: Responding to New Expectations for Competence and Accountability (pp. 229-261. San Francisco: Jossey-Bass.

NASPAA Commission on Peer Review and Accreditation. (2009). NASPAA Accreditation Standards for Master's Degree Programs. Retrieved from http://www. naspaa.org/accreditation/ns/naspaastandards.asp

Op de Beeck, S., \& Hondeghem, A. (2010). Managing competencies in government: State of the art practices and issues at stake for the future. Organization for Economic Cooperation and Development (OECD). Retrieved from http://search.oecd.org/officialdo cumentsdisplaydocumentpdf $/$ ?cote $=\mathrm{GOV} / \mathrm{PGC} /$ $\operatorname{PEM}(2010) 1 \&$ doclanguage $=$ en

Perlin, M. S. (2011). Curriculum mapping for program evaluation and CAHME accreditation. Journal of Health Administration Education, 28(1), 27-47.

Powell, D., Piskulich, M., \& Saint-Germain, M. (2011). Expectationsfor Student Learning Outcomes Assessment for NASPAA-COPRA Accreditation. Retrieved from http://www.naspaa.org/accreditation/NS/24\%20 COPRA\%20Appendix $\% 204 \% 20$ White $\% 20$ Paper\%20Competencies.pdf

Putre, L. (2013). The march of the Millennials. Your hospital staff in 2025: The same, only different. Hospitals \& Health Networks, 87(9), 38-40.

Shewchuk, R. M., O'Connor, S. J., \& Fine, D. J. (2006). Bridging the gap: Academic and practitioner perspectives to identify early career competencies needed in healthcare management. Journal of Health Administration Education, 23(4), 367-392.

Spady, W. G. (1978, October). The concept and implications of competency-based education. Educational Leadership, 16-22.

Stefl, M. E. (2008). Common competencies for all healthcare managers: The healthcare leadership alliance model. Journal of Healthcare Management, 53(6), 360-373. 
Stensaker, B. (2011). Accreditation of higher education in Europe: Moving toward the U.S. model? Journal of Education Policy, 26(6), 757-769.

Van Gelder, M., \& Dougherty Jr., W. G. (2012). Do students with experience know that much more? Assessing in-service and pre-service differences in public administration students. Journal of Public Affairs Education, 18(2), 349-374.

White, K. R., Clement, D. G., \& Nayar, P. (2006). Evidence-based healthcare management competency evaluation: Alumni perceptions. Journal of Health Administration Education, 23(4), 335-349.

\section{ABOUT THE AUTHORS}

Jill Jamison Rissi, PhD, is an assistant professor of Public Administration in the Hatfield School of Government at Portland State University. Drawing on her clinical, administrative, and public service background, her research focuses on the nexus of public policy, health system infrastructure, and population health. She has served as an accreditation Fellow for CAHME and is currently involved in multiple studies of national and state-level health system transformation.

Sherril B. Gelmon, DrPH, is professor of Public Health and chair of Public Administration in the Mark O. Hatfield School of Government at Portland State University. She teaches health services management and policy to graduate students, and leads the $\mathrm{PhD}$ program in Health Systems and Policy. Her scholarly interests include health system workforce development through competency development, assessment, and educational accreditation. 